\title{
National Conference of Theological Librarians
}

A CONFERENCE which is unique in the history of theological librarianship in America was held on June 23-24 at Louisville, Ky. Responding to a call sponsored by the American Association of Theological Schools, fifty-one theological librarians and administrators gathered on the campus of the Louisville Presbyterian Seminary to consider common problems and responsibilities and opportunities of seminary libraries.

Recent years have witnessed rapid growth among the libraries of theological seminaries of the United States and Canada. At present, approximately one hundred and ten theological seminaries are affiliated with the American Association of Theological Schools, whose program of accreditation includes an examination of library facilities, program, personnel, and support. It was in connection with its concern for intensive study of seminary libraries during 1948-50 that the association, at its meeting of June 12, 1946, requested its executive committee to consider the calling of a national conference of theological librarians and of others interested and to make preliminary arrangements for the calling of such conference.

In addition to the discussion of basic problems, attention was given to matters of organization and the execution of specific projects. Tentative approval of a constitution was given, setting up the American Theological Library Association, with provisions for both individual and institutional memberships, and having the following stated purpose:

... to bring its members into closer working relations with each other and with the
American Association of Theological Schocls; to study the distinctive problems of theological seminary libraries, to increase the professional competence of the membership, and to improve the quality of library service to theological education.

The following projects were determined upon, for intensive consideration during the coming year: AATS Booklist, Cataloging and Classification, Periodical Exchange, Religious Periodical Indexing, Publications, Personnel. Officers for the year are: president, L. R. Elliott, Southwestern Baptist Theological Seminary, Ft. Worth, Tex.; vice president, Raymond P. Morris, Yale Divinity School, New Haven, Conn.; secretary, Robert F. Beach, Garrett Biblical Institute, Evanston, Ill.; and treasurer, Ernest M. White, Louisville Presbyterian Seminary, Louisville, Ky. The executive committee consists of the above officers, a representative of the American Association of Theological Schools, and the following members-atlarge: Kenneth S. Gapp, Princeton Theological Seminary, Princeton, N.J.; E. F. George, Evangelical Theological Seminary, Naperville, Ill. ; O. Gerald Lawson, Drew Theological Seminary, Madison, N.J.; Lucy W. Markley, Union Theological Seminary, New York City; and Evah Ostrander, Chicago Theological Seminary.

A full summary of the proceedings of the conference has been prepared. Persons desiring copies are invited to communicate with the secretary, Robert F. Beach. Inquiries and applications for membership in the American Theological Library Association may be directed to the treasurer, Ernest M. White.

Robert F. Beach, Secretary 